\title{
SGPP2 wt Allele
}

National Cancer Institute

\section{Source}

National Cancer Institute. SGPP2 wt Allele. NCI Thesaurus. Code C105045.

Human SGPP2 wild-type allele is located in the vicinity of 2 q36.1 and is approximately 136 kb in length. This allele, which encodes sphingosine-1-phosphate phosphatase 2 protein, is involved in intracellular and extracellular sphingosine-1-phosphate levels. 